\title{
Difficulties experienced by the family concerning the challenges of euthanasia - hopes and illusions
}

\author{
Trudności doświadczane przez rodzinę w przypadku wyzwań związanych \\ z eutanazją - nadzieje i złudzenia
}

\author{
Krzysztof Andrzej Zajdel1,B-D $\odot$ \\ 'Zielonogóra University, Polska \\ A - Koncepcja i projekt badania, B - Gromadzenie i/lub zestawianie danych, C - Analiza i interpretacja danych, \\ $D$ - Napisanie artykułu, E - Krytyczne zrecenzowanie artykułu, F - Zatwierdzenie ostatecznej wersji artykułu
}

Zajdel K.A. Difficulties experienced by the family in the challenges of euthanasia - hopes and illusions. Med Og Nauk Zdr. 2020; 26(1): 48-53. DOI: $10.26444 / \mathrm{monz} / 116315$

\begin{abstract}
Introduction. In the face of the inevitably approaching death, as well as in the face of changes characteristic for old age which affect the quality of everyday life, older people (sometimes in their full strength) are forced to deal with a developing crisis. This may lead to thoughts about euthanasia, about a worthy departure, without suffering, in the family environment. Whether the family will meet these expectations is another issue, as well as a challenge for the law. In this context, it is important how an individual and the family cope with this great challenge of reconciling themselves to the end of their earthly existence, and to what degree they can cope in order to overcome the developing crisis of death in a mature and ethical way.
\end{abstract}

Objectives.The aim of this study is to find an answer to the question: How will we behave in the situation of the challenge of our own death or the passing away of our loved ones?'

Materials and method. The study was conducted on a small sample of 140 individuals with family and children. They were examined with a questionnaire and conclusions drawn from the statements of the respondents, without correlation.

Results. The results may come as a surprise. We think differently about our own passing away, and differently about the passing away of others. The 'possible' decisions are also an important (hypothetical) issue in this respect.

Conclusions. The conclusions are multithreaded: they refer to us as people who may be departing from his life, as well as to our views on the departure of the closest domestic animals.

\section{Key words}

old age, ways to help people in old age, euthanasia, views of potential teachers

\begin{abstract}
Streszczenie
Cel pracy. W obliczu zbliżającej się nieuchronnie śmierci, jak również w przypadku występowania charakterystycznych dla wieku podeszłego zmian wpływających na jakość codziennego życia człowiek w starszym wieku (niekiedy w pełni sił) zmuszony jest do uporania się z kryzysem rozwojowym. To być może skłania go do myślenia o eutanazji, o godnym odejściu, bez cierpienia, w otoczeniu rodziny. Czy rodzina sprosta tym oczekiwaniom, to już inna kwestia, ale także wyzwanie dla prawa. W tym kontekście istotne jest, w jaki sposób człowiek i jego rodzina uporają z tym wielkim wyzwaniem związanym z koniecznością pogodzenia się z kresem ziemskiej egzystencji i na ile potrafią poradzić sobie, by w dojrzały i etyczny sposób przekroczyć kryzys rozwojowy związany ze śmiercią. Celem mojej pracy było znalezienie odpowiedzi na pytanie, jak zachowamy się w sytuacji wyzwania związanego z własnym umieraniem, z odchodzeniem najbliższych. Nie jest łatwo myśleć o śmierci, kiedy jest się młodym i pełnym sił, a jeszcze trudniej, kiedy musimy o tym myśleć.

Materiał i metody. Materiał jest efektem badań przeprowadzonych na niewielkiej próbie 140 osób, posiadających rodzinę i dzieci. W badaniach użyto kwestionariusza ankiety, z deklaracji badanych wyciągano wnioski, bez korelacji.

Wyniki. Wyniki mogą budzić pewne zdziwienie. Inaczej myślimy o własnym odchodzeniu, a inaczej o odchodzeniu innych. Kwestią istotną są też ewentualne (hipotetyczne) decyzje w tym zakresie.

Wnioski. Wnioski są wielowątkowe: odnoszą się do nas jako osób, które być może będą odchodzić, jak i do naszych poglądów na odchodzenie najbliższych osób czy zwierząt domowych. Słowa kluczowe
\end{abstract}

\section{Słowa kluczowe}

starość, sposoby pomocy osobom w podeszłym wieku, eutanazja, poglądy potencjalnych nauczycieli
Address for correspondence: Krzysztof Andrzej Zajdel, University of Zielona Góra, Poland

E-mail:kzajdel@uz.zgora.pl

Received: 21.11.2019; accepted: 07.01.2020; first published: 10.02.2020

\section{INTRODUCTION}

Social and care pedagogy in its research areas deals with people in need of care (among others: children, people with disabilities, seniors), as well as the carers themselves. An important challenge in this respect is also for andragogues, 
as those most frequently needing support on many levels are people at post-working age. On many occasions, the literature has undertaken a multifaceted analyses of the issueof human dignity, from the dignity of a child to the dignity of faith or death. In this light, the issue of care, which is ascribed, inter alia, as care pedagogy, should be supplemented by another dimension, i.e., the dignity of death. Each death should not lead to depression, but should be a stimulus to reflect on the sense of existence, perhaps also to shape faith. It was once said that Death is no different from life.' Can we consider such a statement to be true?

In this context I would like to refer to the notion of how euthanasia is defined. In Western publications there are two definitions:

1) euthanasia is also known as 'merciful killing, the act of giving oneself up to a painless death that allows one to die without extreme medical means. Most often, euthanasia is decided for people suffering with incurable, particularly painful diseases or conditions.

2) Painless death by mercy killing [1]

There are two basic types of euthanasia:

- voluntary euthanasia: carried out with the consent of the patient. Since 2009, voluntary euthanasia has been legal in Belgium, Colombia, Luxembourg, Switzerland, The Netherlands, and the States, Montana, Oregon and Washington in the USA.

- forced euthanasia: involuntary or compulsary euthanasia: carried out without the patient $>$ s consent. The decision is made by another competent person because the patent is in a coma or incapable of rational thought.

There are two classifications of euthanasia, passive and active:

1) Passive euthanasia. Physician-assisted suicide (PAS): when life-support procedures are withheld or stoppel, or It is arguable whether passive euthanasia occurs when doses of pain relieving medication are administered, or whether the medication is passive or active because euthanasia has not yet occurred [2].

2) Active euthanasia. When a doctor administers an increase in the dose of strong painkillers with the intention of causing a swift death for the patient.

Jack Kevorkian, an American pathologist and euthanasia proponent who publicly advocated the right of a terminalny ill person to die by physician-assisted suicide, was the person who contributed to the publicity for euthanasia, and to the decision about his own life. constructed in his old Volkswagen the first machine to kill people for a fee of 30 dollars. He drove it all over the State of Michigan in the USA which earned him the nickname 'Doctor Death'. The van, which was also the deathplace for his patients, was recently sold at auction. The authorities could not convict him of murder because he was not the one who pressed the button that triggered the mechanism to inject the poison into the patient's veins. In 1998, he was sentenced only for his own application of a lethal injection to a patient suffering from atrophic lateral sclerosis, which he showed to millions of Americans in one of the most popular TV programmes in the USA - ' 60 minutes'. The film was the basis for the fifth indictment of Kevorkian for murder, and the doctor in the interview admitted that the authorities must now either convict or release him. This was supposed to be a way to legalize euthanasia in the USA, which is still perceived as an example of Kevorkian`s heroism - a precursor for the needy. [3].

There is another interesting and high-profile issue which is sometimes referred to in the media, namely, euthanasia in Poland. Before referring to this, the issue of the dignity of human life and the laws that defend it must be mentioned. In the Constitution of the Republic of Poland, Chapter II, Article 30 states that: 'The natural and inalienable dignity of man is the source of freedom and rights of man and citizen. It is inviolable, and its respect and protection is a duty of public rights' [4]. Thus, in Polish law, human dignity is inscribed in our lives and principles, and such a provision is ruled by executive regulations (legal regulations). Other documents include legal regulations that were adopted when Poland joined the EU. In the Charter of Fundamental Rights of the European Union, Chapter I, Article 1 states that 'Human dignity is inviolable. It must be respected and protected' [5]. European law thus defends the most important point - human dignity.

There are also provisions in another document, the Resolution(s) of 10 December 1948 which contains postulates according to which one can fight for ones freedom and, above all - dignity. According to this Declaration: 'All people are born free and equal in dignity and rights. They are endowed with reason and conscience and must behave towards others in the spirit of fraternity' [5]. This declaration tells us not only to resect our own dignity, but also to respect the dignity of others.

When the United Nations Assembly adpoted Resolution 217 to promote the Universal Declaration of Human Rights it contained three Articles swoich are of prime importance:

Art. 1: Everyone has the right to life, liberty and security of the person.

Art. 2: Everyone has the right of recognition everywhere as a person before the law.

Art. 3: All are equal before the law and are enabled without any discrimination to equal protection of the law.

These are only a few of the Articles protecting the dignity of all individuals regardless, whether a patient, a child, have a family or live alone in an institution. Expressed briefly, although we have the right to dignity, to a dignified death, on the other hand, we also have the right to life.

Social policy, in its very broad scope covering many spheres of life of the citizens of individual societies, rests on several basic pillars. Its main components are social insurance and so-called 'family supplies'. Diseases, reaching an older age and death are events the inevitability of which obliged political decision-makers to develop a stable system of social insurance benefits [6]. Activity should not be limited only to physical effort, because next to it 'the most important is mental and intellectual activity. If some elderly people, after retirement become ill because they cannot fill their free time, it is connected not only with the feeling that a person has become unnecessary, but also with the lack of mental and physical activity' [7]. On the other hand, 'intellectual activity prevents the loss of self-respect, hopelessness and depression that so often accompanies old age. Physical ailments also decrease, probably because their symptoms, whose etiology is of a psychosomatic nature, disappear or are alleviated' [7].

From a religious point of view, St. Thomas of Aquinas does not call the soul immortal, but indestructible; after Aristotle, he claims that man is a psychophysical unity, and the soul 
is a substance form of the body, i.e. it gives the shape of carnality [8]. One can therefore conclude that human activity consists mainly in satisfying biological, social and cultural needs, and performing tasks resulting from participation in a specific social system, from relations and dependence on the surrounding world environment [9].

In T. Biernata's book we read that:

The answers obtained from young people allow us to state that the concept of euthanasia was known to most people (lack of answers and other answers - 10.8\%). Euthanasia was supported by $52 \%$ of respondents, i.e. every second respondent (the place of residence did not differentiate between the acceptance of euthanasia). Opposition to euthanasia was expressed by $27.6 \%$ of respondents, and $9.4 \%$ of youth did not yet form an opinion on this issue. The support for this practice among youth is higher than in the adult population [10].

(Source:https://wydawnictwo.umk.pl/pl/products/1086/ spoleczno-kulturowe-uwarunkowania-swiatopogladumlodziezy-w-okresie-transformacji).

This means that we have a significant percentage of statements from young people supporting euthanasia for the elderly and the sick. Why is this happening? Perhaps it is only a matter of declarations, because it is easy to declare something anonymously, but in a situation when we would have to make a decision about euthanasia in relation to ourselves or a family member, would such a decision be equally easy? At the age of 17, one's thoughts about heath problems or 'the end of life' are very different from those when one is advanced in years, when perhaps you believe you have no hope, but still have your health and the suport of your family.

What can be offered to the terminally ill? Palliative care may be offered, which is a field of medicine dealing with the treatment of symptoms and the satisfaction of medical needs of patients in the final stage of terminal disease. It is applied when it is no longer possible to extend the patients life by directly influencing the cause of the disease, and the patient/s condition requires medical care. [11]. Palliative medicine is aimed at patients who can no longer count on other medical assistance - it is the final form of assistance for patients. The aim of this care is the fight against pain and other symptoms, as well as psychological, social and spiritual problems. The aim of palliative care is to achieve the best possible quality of life for the patient and the family.

Another form of State care is the hospice. A hospice is defined as:

A programme or specialized care home for terminal patients, a care facility for terminally incurable patients in the final stages of terminal disease, which satisfies the mental, social and physical needs of dying patients and their families, or a place and at the same time a philosophy of care for suffering and/or dying people [12].

However, the self-esteem of hospice patients tends to be low because the knowledge of long-term dependence on others or approaching death is conducive to depression and negative well-being. The majority of authors believe that a hospice is a so-called 'alternative' for sick, handicapped and dying patients because each patient needs the help of specialists 24 hours a day (at least in theory). They are totally dependent on others and their lives depend on the help of those who devote themselves to this vocation.

There is also another form of 24-hour care for chronically ill patients:

(...) created in hospitals (apart from typical hospital wards, which provide acute care in acute cases), which provide inpatient services and 24-hour health care services. Its scope covers patients whose health condition does not allow them to be discharged home, and who require continuing treatment at the department for chronically ill, care and rehabilitation. There are also people who have undergone an acute phase of hospital treatment in shortterm care units and have completed the diagnosis process.

There are also patients who due to their health condition after surgical treatment or intensive conservative treatment, require further hospitalization and need constant medical supervision and professional rehabilitation [13]. Patients staying in these centres receive appropriate assistance for their illnesses. These wards are for patients with chronic diseases. Other forms of care for the chronically ill are Care and Treatment Centres (ZOL) and Care and Care Centres (ZPO).

Euthanasia in selected EU countries. In The Netherlands, a parliamentary law adopted in October 2001, allows euthanasia at the repeated request of a suffering and terminally ill patient. In Belgium, in May 2002, a parliamentary law was adopted that since November 2002 has allowed the use of euthanasia after the submission of three requests by a patient at the terminal stage; this law is more restrictive than in The Netherlands. The United Kingdom is one of the countries where euthanasia is not recognised, but where the so-called 'no cumbersome treatment' is recognised: 'the United Kingdom is a country that recognises the right to withdraw from treatment, or at least not to continue with useless procedures' [14]. In Denmark, Law No. 351 of 14 May 199, amending the medical practice and Law No. 482 of 1 July 1998, concerning the legal status of a patent, entitles a person of legal age and capable of acting legally to write a 'will of life'. Danish law allows a preventive person (?) to request that life should not be maintained in the event of a serious accident. In Sweden, the determination of this question depends to a large extent on judicial practice. Thus, Article 2, Chapter 23, Section 2 of the Penal Code provides for a reduction in the sentence if death is inflicted on another person as an act of compassion. In any case, euthanasia is always regarded in law as a punishable offence [14]. Spain is another country where euthanasia is a criminal offence: a person who, upon explicit, certain and unequivocal request, causes or participates 'actively in acts leading to the death of a person suffering from a serious illness, which must necessarily end in death or cause great and permanent pain, shall be liable to imprisonment for a term of between six months and one year' [14]. This is not surprising because Spain is a Catholic country where religion influences the law.

Of course, there is also the Hippocratic Oath, which formulates certain rules of conduct for doctors, which includes the admonition:

The traditional Hippocratic Oath states (paragraphs 3-5): I will not give a lethal drug to anyone if I am asked, nor will I advise such a plan; and similarly I will not give a woman a pessary to cause an abortion. 
In purity and according to divine law I will carry out my life and my art.

[Source: R. Hulkower, 'The History of the Hippocratic Oath: Outdated, Inauthentic, and Yet Still Relevant', in: The Einstein Journal of Biology and Medicine, Vol. 25, No. 1 (March 2016), pp. 41-44].

If the right to life is violated, one can also rely on patient rights and the Criminal Cod according to which a person can be sentenced for for an injustice, for helping with death.

Research method. It was not the intention of the presented study to test a representative sample, but simply to assess the opinions of a fairly small group of respondents as a contribution to a broader study. The study was conducted using the survey technique and a questionnaire as a tool. The questions had both open and closed criteria. Before the surveys was carried out, the subject of euthanasia was discussed with the students, during which they recounted personal, emotional casus about the passing away of loved ones, often in pain and suffering.

The author accepts that this study is not representative, it presents only the views of a particular age group. The respondents were not analysed or divided according to gender and age, but all of them were parents with children. The study consisted of 140 students from the final year of undergraduate pedagogical studies (3rd year of BA and 2nd year of MA degree, potential teachers). The groups of respondents were studying at two universities: three from a provincial city - Zielona Góra, the other from a small town with 45,000 inhabitants - Brzeg Opolski. What is important is the common factor that all the surveyed students were the parents of children of different ages.

An initial question concerned the euthanasia of animals. Children usually have an animal at home and realize that dogs and cats have shorter lives than humans, and the fact has to be faced that sooner or later they will die. What, then, is our relationship to dying of pets?

Table 1. Students' attitude to euthanasia of domestic animals (percentages)

\begin{tabular}{|c|c|c|c|c|}
\hline \multirow{3}{*}{$\begin{array}{l}\text { I once had an } \\
\text { animal (e.g. cat, } \\
\text { dog, parrot) }\end{array}$} & \multicolumn{2}{|c|}{$\begin{array}{l}\text { Bachelor degree students } \\
\qquad \mathrm{N}=80\end{array}$} & \multicolumn{2}{|c|}{$\begin{array}{l}\text { Master's degree students } \\
\qquad \mathrm{N}=60\end{array}$} \\
\hline & Yes & No & Yes & No \\
\hline & 90 & 10 & 92 & 8 \\
\hline \multirow[b]{2}{*}{$\begin{array}{l}\text { When an animal } \\
\text { is seriously ill, } \\
\text { I am in favour of } \\
\text { putting it out of } \\
\text { its misery, putting } \\
\text { it to sleep. }\end{array}$} & \multicolumn{4}{|c|}{$\begin{array}{l}\text { Statements only of the group of respondents who had an } \\
\qquad \text { animal at home }\end{array}$} \\
\hline & $\begin{array}{r}\text { I definite } \\
\text { I ac } \\
\text { I don't ho } \\
\text { I dons } \\
\text { I definit }\end{array}$ & $\begin{array}{l}\text { vith }-90 \\
-5 \\
\text { entence } \\
\text { th }-0 \\
\text { t agree }\end{array}$ & $\begin{array}{r}\text { I definite } \\
\text { I ag } \\
\text { I don't has } \\
\text { I don`t } \\
\text { I definit }\end{array}$ & $\begin{array}{l}\text { with }-80 \\
-10 \\
\text { sentence. } \\
\text { ith - } 0 \\
\text { t agree }\end{array}$ \\
\hline
\end{tabular}

Are the statements of the respondents surprising? Probably not, because a pet is often treated as a family member and does not always have a 'worthy' departure. When an animal becomes sick and suffers, we often have to clean after it; later, although it is often a difficult decision to make, we agree to have the pet 'put to sleep'. We rarely attend to its burial, agreeing that the vet can 'recycle' the pet. This is what happens with domestic animals, and with those in the household.
We do not cry over a dead cow, pig or chicken, unless it is a material loss. Is it the same with people? My initial questions concerned parents and grandparents - adults.

Table 2. Hypothetical decision-making about the fate of relatives (adults) in the face of incurable disease (percentage)

\begin{tabular}{|c|c|c|}
\hline & $\begin{array}{l}\text { Bachelor degree } \\
\text { students } \\
\mathrm{N}=80\end{array}$ & $\begin{array}{c}\text { Master's degree } \\
\text { students } \\
\mathrm{N}=60\end{array}$ \\
\hline $\begin{array}{l}\text { In a crisis situation, when a binding decision } \\
\text { had to be made, would I continue with } \\
\text { further treatment and sustain the life of } \\
\text { the family member, or would I leave such } \\
\text { a decision to the doctors? }\end{array}$ & 77 & 81 \\
\hline $\begin{array}{l}\text { I would like to make such a decision on my } \\
\text { own }\end{array}$ & 15 & 8 \\
\hline I have no opinion & 8 & 11 \\
\hline
\end{tabular}

In a hypothetical situation in which a specific decision does not have to be made, there is an alternative. A chronically ill person on the verge of death depends on the doctors and the actions they take. In the current study, both groups of respondents, to a large extent, delegated responsibility for such a decision to the doctors. Does this mean that, to a lesser degree, the respondents (15\% and $8 \%$ percent) gave their consent for euthanasia? This answer is not unambiguous, because it refers only to the decision about further treatment. In the spontaneous exchange of opinions after the study, there were such expressions as: 'after all, a miracle can always happen', 'doctors may be wrong', or 'my loved one may not want, e.g. painful treatment', 'therefore, I would like to be able to make such a decision on his/her behalf.' For the most part, the few voices allowing the disconnection of, e.g. life support equipment, or interruption of treatment, or the decision of a patent who communicated this to their relatives and counting on their intervention. If I have a sick person in my family, e.g. parents, grandparents, then 'I trust their fate to God' and I will not make any 'unethical' decision, I will wait for the development of events and for the 'will of God'. One-fifth of the surveyed potential teachers (Bachelors degree) would like to decide about the fate of their loved ones; therefore, what is the situation when an adult family member does not request cessation of treatment, but for death, for the shortening of suffering? (Tab. 3).

Table 3. Decision-making in the case of a request for death by an older family member (percentage)

\begin{tabular}{lcc}
\hline & $\begin{array}{c}\text { Bachelor degree } \\
\text { students } \\
\mathrm{N}=80\end{array}$ & $\begin{array}{c}\text { Master's degree } \\
\text { students } \\
\mathrm{N}=60\end{array}$ \\
\hline I would definitely agree to such a request & 0 & 0 \\
\hline $\begin{array}{l}\text { I would agree to it after consideration/ } \\
\text { consultation with the family }\end{array}$ & 8 & 5 \\
\hline I have no opinion & 10 & 5 \\
\hline I would not agree to such a request & 5 & 5 \\
\hline $\begin{array}{l}\text { I would definitely disagree with such } \\
\text { a request. }\end{array}$ & 77 & 85 \\
\hline
\end{tabular}

These results tell us a great deal about ourselves, about our decisions, should we be asked make them suich decisions 
ourselves. The resondents in the study were reluctant to give such an answer, they asked instead about the condition of the hypothetical patient, whether it was a close or distant family member. Only a low pecentage of $8 \%$ of the undergraduate students acknowledged the right to euthanasia, but only after consultation with their familie, and only in special cases. In the case of the Master s degree students, the ratio was also low $-5 \%$. Generally, there was very high resistance to making such a decision, especially in apersonal situation of, e.g. a mother or father. It is therefore not clear whether such an indication by the respondents at this point in the study would be transferred to an actual decision.

The next problem concerned minor patients - children in a hospice. The first question concerned children in general, the second - the respondents' own children. A hypothetical situation was presented in which, in the opinion of the doctors, a child ss condition was incurable and strong analgesics were being administered. Death was perhaps only a few days away.

Table 4. Decision to accept the euthanasia of an incurably ill child, if such a decision depended on the respondent and was legally admissible (percentage)

\begin{tabular}{lcccc}
\hline & \multicolumn{2}{c}{$\begin{array}{c}\text { Bachelor degree } \\
\text { students } \\
\mathrm{N}=80\end{array}$} & \multicolumn{2}{c}{$\begin{array}{c}\text { Master's degree } \\
\text { students } \\
\mathrm{N}=60\end{array}$} \\
\cline { 2 - 5 } & $\begin{array}{c}\text { Someone } \\
\text { else's child }\end{array}$ & My child & $\begin{array}{c}\text { Someone } \\
\text { else's child }\end{array}$ & My child \\
\hline Consent to euthanasia & 3 & 0 & 5 & 0 \\
\hline I have no opinion & 20 & 0 & 5 & 0 \\
\hline No consent for euthanasia & 77 & 100 & 90 & 100 \\
\hline
\end{tabular}

The respondents> declarations differed slightly in terms of choice in relation to their own or someone elsess child. Own children were more 'protected' and no thought of euthanasia was permissable. In general, with regard to children, the respondents were more cautious about making any decisions than they were about older people. No one in any of the examined groups agreed to the euthanasia of their own child, which probably should not come as a surprise. The few voices in favour of euthanasia of someone else's child may be a statistical error, although in the conversation after the study, there were some who agreed that sometimes it is preferable to shorten the suffering, as one does with a pet, in the belief that children sufler pain more acutely than the elderly.

The penultimate question was: 'What are the reasons for not agreeing to euthanasia, where should the reasons be sought?' Only those who were strongly opposed to euthanasia responded.

Table 5. Reasons for disagreement with euthanasi (percentage)

\begin{tabular}{lcc}
\hline & $\begin{array}{c}\text { Bachelor degree } \\
\text { students } \\
\mathrm{N}=80\end{array}$ & $\begin{array}{c}\text { Master's degree } \\
\text { students } \\
\mathrm{N}=60\end{array}$ \\
\hline Religious motives & 95 & 90 \\
\hline Ethical motives & 90 & 95 \\
\hline Fear of remorse & 95 & 90 \\
\hline $\begin{array}{l}\text { Lack of consent for such behaviour on the } \\
\text { part of relatives who reserved for themselves } \\
\text { such a 'departure' during their lifetime }\end{array}$ & 90 & 85 \\
\hline Other reasons & 5 & 0 \\
\hline
\end{tabular}

Data do not add up to 100 , because respondents could choose more than one answer.
The results of the answers to this question should not be surprising if one examines the statistics for people in Poland who admit to their religious faith. According to the latest census in Poland, whereas more than 34 million Poles are believers, only 929,000 people do not profess to having a faith. It was also observed that while still alive many relatives have directly expressed that they should not be helped to die. Most likely, they were motivated by religious considerations, although this would require separate research. Ethical issues and remorse also strongly determined the lack of consent for assistance in dying.

The last question asked concerned a specific issue, namely, whether the respondents themselves would be comfortable with having to decide their own fate at a time they were suffering from an incurable illness orchronic pain. Would they be in favour of of their own 'mercy death' - euthanasia?

Table 6. Decisions of respondents regarding self-euthanasia in the case of chronic suffering or incurable disease (percentage)

\begin{tabular}{lcc}
\hline $\begin{array}{l}\text { I would like to be able to make a decision } \\
\text { about euthanasia if I were very sick, dying } \\
\text { and suffering }\end{array}$ & $\begin{array}{c}\text { Bachelor degree } \\
\text { students } \\
\mathrm{N}=80\end{array}$ & $\begin{array}{c}\text { Master's degree } \\
\text { students } \\
\mathrm{N}=60\end{array}$ \\
\hline Yes & 80 & 85 \\
\hline No & 10 & 10 \\
\hline I do not have an opinion & 10 & 5 \\
\hline
\end{tabular}

There is a certain contradiction between the previous declarations and the reference to oneself. When hypothetically referring to close adults, such as parents, grandparents or children, the respondents were very restrained when it came to decisons about euthanasia, maliny for religious or ethical motives. With regard to themselves, therefore, the respondents were no longer so determined. Differences could clearly be seen between the generations; in both groups, almost $90 \%$ of family members (parents, grandparents) reserved the right to refuse euthanasia during their lifetime. In the declarations of the students, their attitude to euthanasia on their own is very different from that of the older generation. What is the reason for this difference in opinion? Perhaps because of the possibility to decide about oneself, awareness, discussing it in the media, or fear of pain and suffering? In the decisions made by the students there was no fear of sin or violation of God's will, which had reference in the decisions in relation to other people, but not to oneself.

\section{DISCUSSION}

Such a short article could not raise all the issues related to euthanasia, it was only possible to indicate that it is a big problem that re-occurs in discussions about attempts to legalise euthanasia in opposition to arguments in the defence of life. Polish society is divided on this issue, as can be seen from research and the almost lack of discernment among students of pedagogical studies, those who are potential teachers. In general, they are 'open' to assistance in reducing suffering, should they have to make such a decision, but not when it involves their loved ones.

Regarding euthanasia for animals, this was a much simpler problem to deal with positively - in favour of euthanasia. 
In the case of human suffering, would it not be be better if 'such a procedure' - euthanasia - was performed by the patent alone, without having to ask anyone's opinion, and carried out somewhere in silence and solitude. Then 'we' would no longer have anything to say, it would happen and perhaps we would even feel relief.

A friend who had been helping his sister for more than a year to look after their mother who was suffering from Alzheimer's disease and needed their constant attention, told the author that if the mother had requested euthanasia and if there had been an opportunity to carry it out, he would have done so. However, this admission was made at a time when the friend was not only overtired, but also at a difficult time in his private life. Would he have made such a statement if conditions had been different?

If the problem of euthanasia concerned us personally, would we take our own lives? How can this question be answered when we are still young? How can it be answered in the case of chronic pain and terminal illness, when there is no hope? We tend to look at old age and the certain end of life differently from that of the 'mercy death' of our own child in order to bring an end to insufferable chronic pain.

\section{CONCLUSIONS}

In the face of inevitably approaching death, as well as the changes characteristic of old age affecting the quality of everyday life, the elderly are forced to deal with a developing crisis. As A. Brzezińska and S. S. Hebanowski wrote:

While integrity can be defined as the tendency of the mind to experience order, harmony and meaning in relation to the whole surrounding world, people and its own life, both past and present, despair is connected with the inability to come to terms with the fact that on this one already experienced life, the whole existence ends. (Brzezińska, Hermanowski, 2005, p. 630).

Perhaps this makes one think about euthanasia, about a worthy departure, without suffering, surrounded by the family. Whether and how the family will meet this challenge is another matter, and it is also a challenge for the law. In this context, it is important how the patient and his family deal with this great challenge related to the necessity to come to terms with the end of earthly existence, and how far they can cope with it in a mature and ethical way in order to overcome the developing crisis related to death. Certainly faith will be a great support, perhaps even a rock in this emotive time of crisis.

\section{REFERENCES}

1. World Dictionary http://www.dictionary.com/browse/euthanasia (styczeń 2017).

2. Nordqvist Ch. http://www.medicalnewstoday.com/articles/182951.php (styczeń 2017).

3. Strona o Jacku Kevorkianie: http://wpolityce.pl/polityka/133670rok-temu-zmarl-doktor-smierc-kiedy-sie-umrze-idzie-sie-do-ziemii-przez-dlugi-czas-sie-smierdzi-a-potem-idzie-sie-pod-ziemie (data eksploracji: 22 wrzesień 2014).

4. Konstytucja Rzeczpospolitej Polskiej, art. 30

5. Karta Praw Podstawowych Unii Europejskiej, Chapter I, Article 1.

6. Sierpowska I. Prawo pomocy społecznej, Wolters Kluwer PolskaOficyna, Kraków, 2006, p. 31.

7. Susułowska M. Psychologia starzenia się i starości, PWN, Warszawa; 1989: 105-144.

8. Bolter L., Niedziela, numer 44/2000, dostępny: http://niedziela.pl/ artykul/795/nd/Co-wiemy-o-smierci [dostęp listopad 2017).

9. Pomykało W. Encyklopedia Pedagogiczna, Wyd. Fundacja Innowacja, Warszawa; 2000: 24.

10. Biernat T. Społeczno-kulturowe uwarunkowania światopoglądu młodzieży w okresie transformacji, Wydawnictwo Uniwersytetu Mikołaja Kopernika, Toruń; 2006: 258.

11. Muszala A. Encyklopedia bioetyki: personalizm chrześcijański. Polskie Wydawnictwo Encyklopedyczne, Radom; 2009: 358.

12.Zych A. Człowiek stary w domu pomocy społecznej. Z perspektywy polityki, Oficyna Wydawnicza Impuls, Kraków; 2007: 73.

13. Mielczarek A. Człowiek stary w domu pomocy społecznej. Z perspektywy polityki społecznej i pracy socjalnej, Wydawnictwo Edukacyjne AKAPIT, Toruń; 2010: 67-68.

14. Aumonier N, Beignier B, Letellier P. Eutanazja, Instytut Wydawniczy Pax, Warszawa, 2003: 86-88.

15.http://www.bioslone.pl/obalanie-mitow/hipokrates/przysiegahipokratesa (data eksploracji 22 wrzesień 2017). 